\title{
Connectivity, population structure, and conservation of Ecuadorian green sea turtles
}

\author{
Jaime A. Chaves ${ }^{1,2, *}$, Micaela Peña ${ }^{3}$, Jhonnattan A. Valdés-Uribe ${ }^{1}$, \\ Juan Pablo Muñoz-Pérez ${ }^{1,2,3}$, Felipe Vallejo ${ }^{3}$, Maike Heidemeyer ${ }^{4,5}$, \\ Omar Torres-Carvajal ${ }^{6}$
}

${ }^{1}$ Universidad San Francisco de Quito, Colegio de Ciencias Biológicas y Ambientales, Diego de Robles y Av. Interoceánica, Cumbayá, Quito, Ecuador

${ }^{2}$ Galápagos Science Center, Puerto Baquerizo Moreno, Galápagos, Ecuador

${ }^{3}$ Fundación Equilibrio Azul, PO Box 17116025, Quito, Ecuador

${ }^{4}$ Centro de Investigación en Biología Celular y Molecular CIBCM, Universidad de Costa Rica, Costa Rica

${ }^{5}$ Centro de Restauración de Especies Marinas Amenazadas CREMA, Tibas, Costa Rica

${ }^{6}$ Museo de Zoología, Escuela de Biología, Pontificia Universidad Católica del Ecuador, Avenida 12 de Octubre y Roca, Apartado 17-01-2184, Quito, Ecuador

\begin{abstract}
Studies of highly migratory species that increase our understanding of the dynamics of genetic diversity, migratory routes, and genetic connectivity are essential for informing conservation actions. Genetic data for green turtles Chelonia mydas from Ecuador have only been available from Galápagos Islands (GPS) rookeries, but not from foraging aggregations. Furthermore, green turtles from habitats associated with mainland Ecuador (Machalilla National Park; MNP) have not been sampled. To assess the genetic relationships between nesting and foraging aggregations from these 2 regions and other regional populations, the mitochondrial DNA (mtDNA) control region was sequenced from 133 turtles. Conventional $F_{\mathrm{ST}}$ (haplotype frequency) and $\Phi_{\mathrm{ST}}$ (sequence-based) values were low and non-significant between Ecuadorian rookeries, suggesting high connectivity between these sites located ca. $1000 \mathrm{~km}$ apart. Mixed stock analysis (MSA) indicated a dominant (>94\%) GPS-MNP contribution to both foraging grounds, with small and nearly negligible contributions from other rookeries in the region (e.g. Costa Rica and Mexico). While orphan haplotypes were not included in the MSA because their rookery of origin is not known, their close genetic relationships to Western and Central Pacific mtDNA clades suggests that a relatively large percentage of turtles at the combined foraging sites ( $>10 \%)$ have been involved in transoceanic migration events. The genetic links between GPS and MNP C. mydas nesting populations revealed by our study highlight the need to incorporate the nesting populations from coastal Ecuador in more comprehensive future conservation planning.
\end{abstract}

KEY WORDS: Chelonia mydas · Galápagos · Machalilla · Connectivity · Ecuador · Conservation · Mixed stock analysis · Phylogenetics

\section{INTRODUCTION}

Phylogeographic studies of highly vagile species are important to an understanding of broad patterns of dispersal, as well as to identify important regions

*Corresponding author: jaimechaves76@gmail.com for the species' conservation. The use of genetic information provides a comprehensive account of population structure, connectivity, and overall demographic patterns of populations (Bowen \& Karl 2007, Seminoff et al. 2008, Shamblin et al. 2012, Joseph et restricted. Authors and original publication must be credited. 
al. 2016). Obtaining genetic information, however, is particularly challenging in marine environments where physical barriers for gene flow are less evident and dispersal potential is high (Ward et al. 1994). Geographically dispersed populations can impose logistical and financial limitations on sufficient sampling of representative breeding and feeding populations. For instance, the circumtropical green turtle Chelonia mydas has the widest and most continuous distribution of all hard-shelled sea turtle species (Vieyra 2006). Previous work on C. mydas shows that regional genetic structure has been shaped by both intrinsic (behavior and ecology) and extrinsic (geographic, climate, and oceanography) events (Seminoff et al. 2008, Roden et al. 2013, Dutton et al. 2014a, Hamabata et al. 2014). For example, current levels of genetic diversity are potentially the result of glacial and inter-glacial paleo-oceanic periods that created opportunities for the establishment of new migratory routes (Formia et al. 2006, Hamabata et al. 2014). Genetic differentiation between Pacific and Atlantic basin populations is most likely the consequence of the formation of the Isthmus of Panama that imposed a barrier to gene flow between these oceans (Bowen et al. 1992, Bowen \& Karl 2007, Naro-Maciel et al. 2008, Wallace et al. 2010, Duchene et al. 2012). Defining genetic clusters of green turtles across their broad geographic range has allowed delineation of Management Units (MUs) for conservation in several regions (Moritz 1994, Dethmers et al. 2006, Dutton et al. 2014a,b) within broader geographic regional MUs (see Wallace et al. 2010). Nonetheless, many green turtle rookeries along the coast of the southeast Pacific Ocean remain understudied, which limits both our understanding of evolutionary pathways and the identification of potentially new MUs.

The life history of the green turtle involves an early oceanic epipelagic phase lasting several years (Carr 1987) followed by a less vagile stage that is associated with neritic foraging grounds (Musick et al. 1997, Luschi et al. 2003) that commonly host individuals from a mixture of rookeries (Moncada et al. 2006, Bowen \& Karl 2007). Green turtles show philopatry (Mayr 1963) and eventually return to their natal beaches, which can be hundreds or thousands of kilometers from their foraging areas, for reproduction (Lohmann et al. 1997, Bolten 2003). Reproductive stocks can be identified through the use of mitochondrial DNA (mtDNA) sequences (Bowen et al. 1992). Moreover, given the genetic distinctiveness of nesting stocks, their relative contributions to a given foraging ground can be estimated with mixed stock analysis (MSA) (Bolker et al. 2003). The MSA method has the advantage over the traditional mark-recapture techniques in that it can be applied to individuals belonging to both genders and all size classes (Jensen 2010, Jensen et al. 2013, 2016), can involve modest sample sizes, and requires only a relatively short period of time to complete (Read et al. 2014). Despite numerous studies using MSA in marine turtles (Bass \& Witzell 2000, Engstrom et al. 2002, Dutton et al. 2008, Jensen 2010, Nishizawa et al. 2013, Jensen et al. 2016, Joseph et al. 2016), important sampling gaps from Eastern Pacific (EP) populations remain, including the breeding populations nesting on mainland Ecuador. Furthermore, limited information exists on the levels of connectivity between foraging and nesting habitats, with only a few MSAs for the region (Amorocho et al. 2012, Heidemeyer 2015).

We examined a previously unstudied rookery of green turtles from the Pacific coast of mainland Ecuador at Machalilla National Park (MNP) in order to fill a void of genetic information from that region. The MNP contains the largest reported breeding population of green turtles along the coast of Ecuador, with the greatest number recorded at Isla de la Plata (ca. 470 total nests reported from nesting seasons 2008 to 2010) and fewer nests per area recorded from coastal sites at Drake Bay ( $\mathrm{n}=73$ nests) and La Playita ( $\mathrm{n}=7$ nests) (Peña-Mosquera 2010, Anhalzer et al. 2012). Unfortunately, green turtles at MNP face important conservation challenges (e.g. presence of feral dogs, illegal nest harvesting, urbanization, light pollution, beach motor traffic, garbage) as do olive ridleys Lepidochelys olivacea and hawksbill turtles Eretmochelys imbricata that also nest in this area (Peña-Mosquera 2010, Mast et al. 2016). Previous genetic work in Ecuador focused solely on females nesting on the Galápagos Islands (Dutton et al. 2014a, Naro-Maciel et al. 2014) but did not assay the foraging aggregations in the waters off these islands. Galápagos rookeries (GPS) apparently constitute a single individual genetic stock (the Galápagos MU; Dutton et al. 2014a) that has very limited connectivity to other rookeries across the EP. Some rookeries that are separated by a distance of approximately $500 \mathrm{~km}$ or more are commonly considered independent genetic stocks (Dethmers et al. 2006, Browne et al. 2010, Dutton et al. 2014a, Shamblin et al. 2015). Thus the distance between MNP and GPS rookeries (ca. $1000 \mathrm{~km}$ ) would suggest that these populations should be genetically independent (i.e. distinguishable genetic stock and possibly new MU), although no genetic data are currently available that confirm a lack of connectivity between the rookeries. 
In this study, we used mtDNA sequences to (1) determine the genetic relationships and connectivity between green turtle rookeries in MNP and GPS, (2) evaluate genetic composition at foraging grounds in MNP and GPS, (3) estimate the origin of orphan haplotypes (i.e. unknown rookery of origin) from phylogenetic trees, and (4) assess the extent of the Galápagos MU in the Southeast Pacific.

\section{MATERIALS AND METHODS}

\section{Study area and data collection}

Samples were collected from both nesting and foraging aggregations along continental-coastal Ecuador at MNP, Manabí province, western Ecuador. The MNP $\left(01^{\circ} 31^{\prime} 00^{\prime \prime} \mathrm{S}, 80^{\circ} 42^{\prime} 00^{\prime \prime} \mathrm{W}\right)$ has a land area of ca. $551 \mathrm{~km}^{2}$ and extends 2 nautical miles (ca. $3.7 \mathrm{~km}$ ) along the coast and around Isla de la Plata (PeñaMosquera et al. 2009). Isla de la Plata (1¹6' 55" S, $81^{\circ} 3^{\prime} 84^{\prime \prime} \mathrm{W}$ ) is a $14 \mathrm{~km}^{2}$ continental island located $40 \mathrm{~km}$ from mainland Ecuador and known for presenting the highest concentrations of nesting green

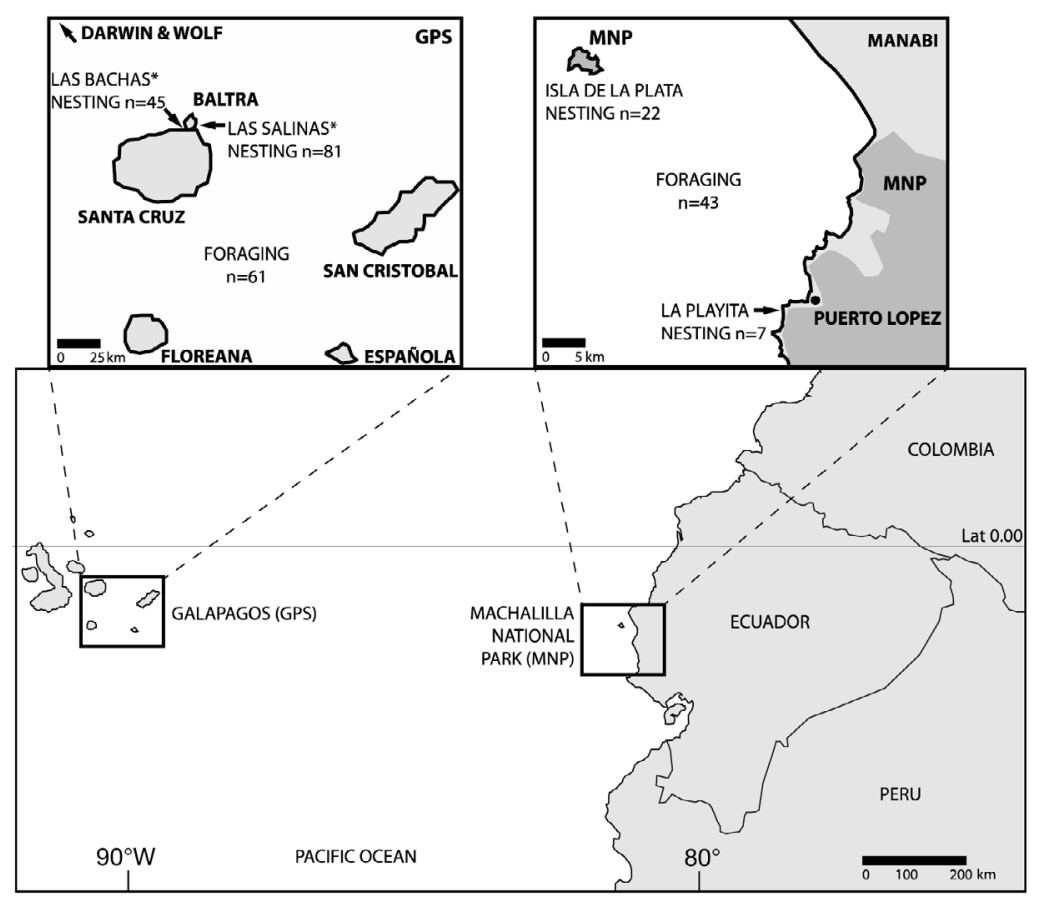

Fig. 1. Location of study sites in Ecuador. Boxes correspond to Galápagos (GPS) and Machalilla National Park (MNP) sampling locations, separated by ca. $1000 \mathrm{~km}$. Gray area in MNP corresponds to the protected zone of the park (including Isla de la Plata, located ca. $40 \mathrm{~km}$ from the mainland). Names with nesting and foraging numbers represent locations and number of individuals sampled. Names with asterisks correspond to sites sampled by Dutton et al. (2014a) used in this study turtles along the coast of Ecuador (Peña-Mosquera et al. 2009, Peña-Mosquera 2010) and the Pacific coast of South America (Mast et al. 2016). Nesting aggregations were sampled at beaches of La Playita on the mainland and of Isla de la Plata, and foraging aggregations were sampled around Isla de la Plata and off the coast of Puerto López on the mainland. Samples from GPS were collected from foraging aggregations around San Cristóbal, Española, Floreana, Darwin, and Wolf Islands (Fig. 1).

We obtained tissue samples (skin biopsies) for DNA extraction from a total of 133 green turtles: 43 from foraging aggregations at Puerto López and Isla de la Plata, herein considered as a single foraging aggregation given their geographic proximity (Fig. 1), 29 from nesting aggregations at MNP beaches ( 7 from La Playita and 22 from Isla de la Plata), and 61 from different foraging aggregations in the Galápagos Islands. Turtles were captured by direct swimand-catch or while monitoring reproductive females during nesting activities at beaches. Morphometric measurements were taken with a flexible measuring tape: curved carapace length (CCL), curved carapace width (CCW), and total tail length (TTL) as per standard methods. We used a power hang scale (Do-All Outdoors) to obtain mass $( \pm 0.5 \mathrm{~kg})$ of turtles at the foraging grounds. Individuals were uniquely marked using Iconel tags placed on flippers, thereby avoiding pseudoreplication that would result from duplicate sampling of individuals. Turtles sampled at foraging grounds were returned to the site of capture. Because the sex of an immature green turtle cannot be determined with confidence on the basis of an external examination (Bolten \& Bjorndal 1992), we used a cut-off size of $70 \mathrm{~cm} \mathrm{CCL}$ to discriminate immature from mature individuals (Amorocho et al. 2012). This is consistent with the mean nesting size of reproductive females at GPS, where 2 modal values of 80 and $95 \mathrm{~cm}$ CCL have been recorded, with the smallest nesting female documented for the archipelago at $60.7 \mathrm{~cm}$ CCL (Zárate 2002). The sex of green turtles with CCL $>70 \mathrm{~cm}$ was determined based on sexual dimorphism presented in Chelonia mydas (Wibbels 1999, Wyneken et al. 2013). Thereafter, 
mature adult males were categorized as individuals presenting tail measurements of $25 \mathrm{~cm}$ (or longer) (Hamann et al. 2006). Skin biopsies were preserved in $90 \%$ ethanol in the field, and stored at $-80^{\circ} \mathrm{C}$. All of the sequences for GPS rookeries incorporated into this study ( $\mathrm{n}=126$ : 45 from Las Bachas on Santa Cruz Island and 81 from Las Salinas on Baltra Island) were downloaded from GenBank and correspond to the work by Dutton et al. (2014a).

\section{Laboratory analysis}

Mitochondrial DNA (mtDNA) was isolated from tissue using a Qiagen DNeasy ${ }^{\circledR}$ Blood \& Tissue Kit following the manufacturer's protocol, and DNA quality and concentration were measured with Nanodrop 1000 (ThermoScientific). Primers LTEi9 (5'-GAA TAA TCA AAA GAG AAG G-3') and H950 (5'-GTC TCG GAT TTA GGG GTT T-3') (Abreu-Grobois et al. 2006) were used in a polymerase chain reaction (PCR) to amplify a $832 \mathrm{bp}$ fragment of the control region. PCR was performed in 25 to $50 \mu$ l total volumes with cocktail concentrations of $1 \times$ buffer, $1.25 \mathrm{mM}$ of each deoxynucleoside triphosphate (dNTPs), $1.5 \mathrm{mM}$ $\mathrm{MgCl}_{2}, 10 \mu \mathrm{M}$ of each primer, $1.25 \mathrm{U}$ Taq polymerase, and $\sim 40 \mathrm{ng}$ of template DNA. Amplification was run under an initial denaturation at $94-96^{\circ} \mathrm{C}$ for $3 \mathrm{~min}$, followed by 35 to 45 cycles of denaturation at $94-96^{\circ} \mathrm{C}$ for $30 \mathrm{~s}$, annealing of primers at $55^{\circ} \mathrm{C}$ for $30 \mathrm{~s}$, and extension of primers and elongation at $72^{\circ} \mathrm{C}$ for $10 \mathrm{~min}$. To detect PCR products, $3 \mu \mathrm{l}$ aliquots of product were run on $1 \%$ agarose gels stained with SYBR® Safe (Invitrogen) and visualized with Biorad Gel Doc XR (BIORAD) for photo-documentation. PCR products were purified with $20 \%$ ExoSap reactions following the manufacturer's protocol. All samples were sequenced by Macrogen (Seoul).

\section{Statistical analysis}

Sequences were aligned using Geneious Basic v.8.0.5 (www.geneious.com, Kearse et al. 2012) under default settings for Geneious Alignment against reference GenBank haplotypes (Table S1 in the Supplement at www.int-res.com/articles/suppl/n032p251 _supp.pdf). Novel haplotypes were assigned the standard nomenclature $C m P$ for $C$. mydas, with a suffix added to denote the sampling locality of the haplotype (see Dutton et al. 2008, 2014a). Genetic comparisons between the Ecuadorian rookeries and foraging aggregations (GPS and MNP) were assessed based on several estimates of genetic differentiation: haplotype frequencies, haplotype diversity $(h)$, and nucleotide diversity $(\pi)$. Population structure was tested by conducting analysis of molecular variance (AMOVA), pairwise $F_{\mathrm{ST}}$ comparisons, and pairwise exact test of population differentiation. Both sequencebased $\Phi_{\mathrm{ST}}$ and conventional $F_{\mathrm{ST}}$ distance measures (10 000 permutations) (Reynolds et al. 1983) were used to calculate within- and among-population diversity in Arlequin v. 2.0 (Schneider et al. 2000). The same steps were taken to compare foraging aggregations in MNP and GPS. Because Western Pacific (WP) haplotypes were found frequently in the foraging aggregations, we replicated these analyses removing WP haplotypes.

\section{Phylogenetic analysis}

The best fitting model of evolution for the locus in the studied populations $(\mathrm{TrN}+\mathrm{I})$ was determined with jModelTest v.0.1.1 (Posada 2008) via Akaike's information criterion (AIC, Burnham \& Anderson 2002). A phylogenetic reconstruction primarily to investigate the origin of several orphan haplotypes found in Ecuadorian foraging aggregations was conducted using Bayesian inference in MrBayes v.3.2 (Ronquist \& Huelsenbeck 2003), with 2 runs of 4 simultaneous Markov chains, each for 10 million generations, and sampling of parameters and trees every 1000 generations. Convergence of the chains was confirmed using TRACER v.1.4 (Rambaut \& Drummond 2007) and AWTY (Nylander et al. 2008), followed by a $25 \%$ burn-in of all retrieved trees to calculate posterior probabilities in a $50 \%$ majority-rule consensus tree. We used Natator depressus (GenBank accession no. U40662) as an outgroup (Duchene et al. 2012), as well as additional sequences from GenBank from EP rookeries that nested at Michoacán, Revillagigedos Islands, and Costa Rica, from Central Pacific (CP) rookeries in Hawaii (Dutton et al. 2014a, Heidemeyer 2015), and from WP populations nesting on American Samoa, the Republic of the Marshall Islands, and Ulithi Atoll-Yap (Dutton et al. 2014b). We also reconstructed a time-calibrated tree under a relaxed-clock framework in BEAST v.1.7.5 (Drummond \& Rambaut 2007), after rejection of a global molecular clock (likelihood ratio test, Felsenstein 1981). The tree was calibrated using 0.01751 substitutions site ${ }^{-1}$ lineage $^{-1}$ million $\mathrm{yr}^{-1}$ as the rate of evolution of the mtDNA control region of green turtles (Formia et al. 2006). Our analyses were performed for 10 million generations using a random starting tree (tree prior specia- 
tion: Yule process). Stationarity, high effective sample sizes (ESS > 200), and 95\% highest posterior density intervals (HPDs) were evaluated for all parameters in TRACER (Rambaut \& Drummond 2007). A consensus tree with divergence times was obtained for unique green turtle sequences after discarding the first $25 \%$ of sampled trees. Finally, to represent intraspecific phylogenies and geographic distribution of genetic diversity of Ecuadorian haplotypes in relation to the EP region, a minimum-spanning network of absolute distances between mtDNA haplotypes was constructed using TCS v.1.2.2 (Clement et al. 2000) and Arlequin v. 2.0 (Schneider et al. 2000) using all published nesting haplotypes from Dutton et al. (2014a) (see Fig. 3).

\section{MSA of Ecuadorian foraging populations}

The contributions of distinct nesting aggregations to the MNP and GPS green turtle foraging grounds were estimated with Bayesian MSA using the program Bayes (Pella \& Masuda 2001). Source haplotype frequencies were taken from published nesting stock characterizations from the EP sites Michoacán, Revillagigedos (Mexico), Nombre de Jesús (Costa Rica), and Galápagos, as well as the CP Hawaiian archipelago (Table S1). Given that one of the haplotypes sampled in the MNP has an identified origin in WP rookeries (CmP22.1; Dutton et al. 2014b), haplotypes from American Samoa, Marshall Islands, and Ulithi Atoll were also included in the MSA. The MSA was conducted using both uniform (flat: equal values for each stock) and informed (weighted: different values) priors (Table S2 in the Supplement). Using informed priors allows incorporating knowledge of the species to provide a stronger and more biologically meaningful result in cases where genetic structure is weak (Jensen et al. 2013). We used 'rookery population size' and 'geographic distance' from sources as weighted priors, as these are widely used in MSA and influence the estimated composition of the foraging grounds (Proietti et al. 2012). 'Geographic distance' prior was set for each stock as the distance from the putative stock to the foraging area, over the sum of distances from all stocks to the foraging area. These distances were obtained using Google Earth. 'Population size' prior was set as the proportion of the size of each stock to the total population size derived by the summation of all stock abundances included in the analysis (Table S2). For each of the 3 models (uniform, geographic distance, and rookery population size), a total of 50000 Markov Chain Monte Carlo generations were run for 8 chains from MNP foraging grounds and 5 chains from GPS foraging aggregations. Each of the chains was given a different starting point, and the number of chains corresponded to the potential source origins used for MNP and GPS (see above). Posterior distribution was calculated using a burn-in of 25000 runs, and the shrink factor of Gelman \& Rubin (1992) was calculated to test if chains had converged. We excluded individuals with haplotypes not found in any nesting rookery (orphan haplotypes) because they were uninformative.

\section{RESULTS}

\section{Sequence diversity in Ecuador}

Genetic analysis of the 133 Ecuadorian samples resolved a total of 14 haplotypes. From the 29 individuals sampled in the MNP rookery, only 4 haplotypes were recovered $(\mathrm{CmP4} .1, \mathrm{CmP4.4}, \mathrm{CmP4.6}$, and

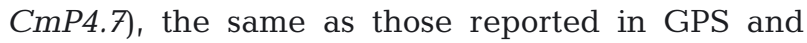
other nesting individuals in the EP (Table 1) (Michoacán and Costa Rica; Dutton et al. 2014a). When combining our results with those from the previously published literature, these 4 haplotypes were found to be the most common in the Ecuadorian rookeries, occurring in 143 of 259 individuals for GPS beaches, and 79 of 259 individuals for both foraging grounds (Table 1). Only 3 haplotypes previously reported in GPS rookeries were not found in this study (see Dutton et al. 2008). One of the haplotypes found in nesting individuals in continental Ecuador ( $\mathrm{Cmp4.1}$ ) has also been reported in other foraging aggregations across the EP (Japan: Hamabata et al. 2014) and CP (Palmyra Atoll; Naro-Maciel et al. 2014). The other 10 haplotypes recovered in this study were found only at foraging aggregations: 3 only found in MNP, 4 only found in GPS, and 3 were shared between these 2 foraging populations (Table 1). Three out of the 10 haplotypes have also been previously reported for GPS rookeries (Dutton et al. 2014a). Interestingly, 1 individual sampled at the MNP foraging aggregations carried haplotype $C m P 22.1$, which is known to occur at nesting rookeries in the CP (see below; Dutton et al. 2014a). Therefore, 6 out of the 10 haplotypes were categorized as 'orphan' as they have not been reported in any rookery, including 3 new haplotypes reported here for the first time $(\mathrm{CmP93.2}$, CmP4.19, and CmP112.1; GenBank accession numbers KY350180, KX499513, and KY350181, respectively). Although $C m P 112.1$ and $C m P 4.19$ have been previously identified in foraging individuals in GPS 
Table 1. mtDNA haplotype profiles in Ecuadorian green turtle Chelonia mydas habitats along with their GenBank accession numbers. Haplotype names follow conventional nomenclature. 'GPS nesting' column corresponds to Galápagos (GPS) rookeries data from Dutton et al. (2014a); sources for the other data are listed in the 'Reference' column. MNP: Machalilla National Park

\begin{tabular}{|c|c|c|c|c|c|c|c|}
\hline Haplotype & $\begin{array}{c}\text { MNP } \\
\text { foraging }\end{array}$ & $\begin{array}{c}\text { MNP } \\
\text { nesting }\end{array}$ & $\begin{array}{c}\text { GPS } \\
\text { foraging }\end{array}$ & $\begin{array}{c}\text { GPS } \\
\text { nesting }\end{array}$ & Total & $\begin{array}{l}\text { GenBank } \\
\text { acc. no. }\end{array}$ & Reference \\
\hline $\mathrm{CmP4.1}$ & 11 & 3 & 13 & 26 & 53 & KC306666 & Dutton et al. (2014a) \\
\hline $\mathrm{CmP} 4.4$ & 2 & 2 & 2 & 6 & 12 & KC306665 & Dutton et al. (2014a) \\
\hline CmP4.6 & 18 & 12 & 16 & 51 & 97 & KC306647 & Dutton et al. (2014a) \\
\hline $\mathrm{CmP} 4.7$ & 5 & 12 & 12 & 31 & 60 & KC306660 & Dutton et al. (2014a) \\
\hline CmP4.9 & 0 & 0 & 0 & 1 & 1 & KC306643 & Dutton et al. (2014a) \\
\hline $\mathrm{CmP4.11}$ & 0 & 0 & 0 & 1 & 1 & KC306661 & Dutton et al. (2014a) \\
\hline$C m P 4.15^{\mathrm{a}}$ & 0 & 0 & 1 & 0 & 1 & KX499506 & Dutton et al. (2014a) \\
\hline $\mathrm{CmP15.1}$ & 0 & 0 & 1 & 3 & 4 & KC306649 & Dutton et al. (2014a) \\
\hline $\mathrm{CmP17.1}$ & 1 & 0 & 2 & 4 & 7 & KC306648 & Dutton et al. (2014a) \\
\hline CmP24.1 & 2 & 0 & 0 & 1 & 3 & KC306646 & Dutton et al. (2014a) \\
\hline $\mathrm{CmP} 22.1$ & 1 & 0 & 0 & 0 & 1 & KF311747 & Dutton et al. (2014b) \\
\hline CmP93.1 & 0 & 0 & 0 & 2 & 2 & FJ917194 & Dutton et al. (2014a) \\
\hline CmP93.2 $2^{\mathrm{b}}$ & 1 & 0 & 1 & 0 & 2 & KY350180 & This study \\
\hline$C m P 97.1^{\mathrm{a}}$ & 1 & 0 & 9 & 0 & 10 & FJ917198 & P. H. Dutton et al. (unpubl.) \\
\hline CmP94.1 $1^{\mathrm{a}}$ & 1 & 0 & 0 & 0 & 1 & FJ917193 & P. H. Dutton et al. (unpubl.) \\
\hline$C m P 112.1^{\mathrm{b}}$ & 0 & 0 & 3 & 0 & 3 & KY350181 & This study \\
\hline $\mathrm{CmP} 4.19^{\mathrm{b}}$ & 0 & 0 & 1 & 0 & 1 & KX499513 & This study \\
\hline Total & 43 & 29 & 61 & 126 & 259 & & \\
\hline
\end{tabular}

(P. H. Dutton et al. pers. comm.) and Costa Rica (M. Heidemeyer unpubl.), these sequences have not previously been published. A fourth orphan haplotype, $\mathrm{CmP4.15}$, recently reported in Gorgona Islands in Colombia (M. Sanchez pers. comm.), was found in GPS foraging aggregations. The last 2 orphan haplotypes in MNP and GPS foraging grounds (CmP97.1 and CmP94.1) were reported as orphan in the $\mathrm{CP}$ (Palmyra Atoll: Naro-Maciel et al. 2014).

As mentioned previously, 4 haplotypes were the most dominant types across all habitats. At the MNP nesting aggregations, haplotypes CmP4. 6 and $C m P 4.7$ were present at high frequencies, each with 12 individuals out of the 29 sampled $(41.3 \%)$. In GPS nesting individuals, the 3 haplotypes with the highest frequencies were CmP4.6 $(\mathrm{n}=51$; $40.5 \%), C m P 4.7(\mathrm{n}=31 ; 24.6 \%)$, and CmP4.1 (n $=26 ; 20.6 \%$ ) out of the 126 individuals analyzed by Dutton et al. (2014a). The MNP foraging aggregations were dominated by haplotypes CmP4.6 and CmP4.1 $(\mathrm{n}=18 ; 41.8 \%$ and $\mathrm{n}=11 ; 25.5 \%$, respectively). Finally, GPS foraging individuals $(\mathrm{n}=61)$ presented haplotypes CmP4.6, CmP4.1, and CmP4.7 in similar frequencies $(\mathrm{n}=16,26.2 \% ; \mathrm{n}=13,21.3 \%$; and $\mathrm{n}=12,19.6 \%$, respectively).
The Ecuadorian nesting aggregation at MNP had a moderate $h$ of 0.665 and low $\pi$ of 0.002 (Table 2), indicating the presence of genetically similar haplotypes. In contrast, these estimates were substantially higher at both MNP and GPS foraging aggregations, where $h$ was 0.749 and 0.831 , respectively, indicating the abundance of haplotypes with origins other than Ecuadorian nesting grounds. Nucleotide diversity at the MNP foraging ground was moderate, with $\pi=$ 0.004, and almost 4 times higher at the GPS foraging aggregation, with $\pi=0.013$, which reflects the abun-

Table 2. Mitochondrial control region sequence diversity for Ecuadorian green turtles Chelonia mydas. Sample size (n), number of haplotypes (H), nucleotide diversity $(\pi$, with standard deviation, SD), and haplotype diversity ( $h$, with SD) values are shown. Data for Galápagos (GPS) rookeries were taken from Dutton et al. (2014a). Values for GPS and Machalilla National Park (MNP) foraging aggregations (bottom row for each location) correspond to results without Western Pacific haplotypes

\begin{tabular}{|lrrcccc|}
\hline Location & $\mathrm{n}$ & $\mathrm{H}$ & $\pi$ & $\mathrm{SD}$ & $h$ & $\mathrm{SD}$ \\
\hline MNP rookery & 29 & 4 & 0.002 & 0.0014 & 0.665 & 0.0507 \\
MNP foraging aggregations & 43 & 10 & 0.004 & 0.0027 & 0.749 & 0.0511 \\
& 41 & 8 & 0.002 & 0.0017 & 0.731 & 0.0505 \\
GPS rookeries & 126 & 10 & 0.001 & 0.0010 & 0.734 & 0.0234 \\
GPS foraging aggregations & 61 & 11 & 0.013 & 0.0069 & 0.831 & 0.0225 \\
& 49 & 9 & 0.002 & 0.0014 & 0.773 & 0.0306 \\
\hline
\end{tabular}


Table 3. Pairwise $F_{\mathrm{ST}}, \Phi_{\mathrm{ST}}$, and Fisher's exact test for population differentiation between: (1) Galápagos (GPS) and Machalilla National Park (MNP) rookeries, (2) GPS and MNP foraging aggregations, and (3) GPS and MNP foraging aggregations without Western Pacific (WP) haplotypes (no WP). Significance values from Arlequin were at the 0.05 level

\begin{tabular}{|lccc|}
\hline & $F_{\mathrm{ST}}$ & $\Phi_{\mathrm{ST}}$ & Exact test \\
\hline Rookeries & $0.0073(\mathrm{p}>0.05)$ & $0.052(\mathrm{p}>0.05)$ & $0.738(\mathrm{p}>0.05)$ \\
Foraging & $0.0097(\mathrm{p}>0.05)$ & $0.025(\mathrm{p}>0.05)$ & $0.106(\mathrm{p}>0.05)$ \\
Foraging (no WP) & $0.014(\mathrm{p}>0.05)$ & $0.0643(\mathrm{p}=0.018)$ & $0.600(\mathrm{p}>0.05)$ \\
\hline
\end{tabular}

affinity of Cmp4.19 (Dutton et al. 2014a) and Cmp4.15 from foraging aggregations from GPS to haplotypes CmP93.2 and CmP4.6 (Dutton et al. 2014a) from rookeries at GPS, MNP, Michoacán, and Costa Rica. Although haplotype Cmp4.6 was found in the EP Clade III by Dutton et al. (2014a), our phylogenetic reconstruction placed it within samples that correspond to EP Clade II. Surprisingly, 3 haplotypes found in GPS and MNP

dance of genetically distant haplotypes endemic to the WP (see below; Table 2). These values were much lower $(\pi=0.002)$ when we removed WP haplotypes from the analysis (Table 2).

\section{Population structure}

There was no significant genetic differentiation between the 2 Ecuadorian nesting populations (Table 3), suggesting genetic connectivity between GPS and $\operatorname{MNP}\left(F_{\mathrm{ST}}=0.0073, \mathrm{p}>0.05 ; \Phi_{\mathrm{ST}}=0.052, \mathrm{p}>0.05\right)$. Foraging aggregations without WP haplotypes followed the same pattern as nesting populations of little genetic differentiation $\left(F_{\mathrm{ST}}=0.0097, \mathrm{p}>0.05 ; \Phi_{\mathrm{ST}}\right.$ $=0.025, \mathrm{p}>0.05)$, with most of the variation explained within populations (AMOVA). When WP haplotypes were incorporated into the analysis, only sequence-based $\Phi_{\mathrm{ST}}$ distance measures were significant $\left(F_{\mathrm{ST}}=0.014, \mathrm{p}>0.05 ; \Phi_{\mathrm{ST}}=0.0643, \mathrm{p}=0.018\right)$, with a small proportion of variance $(\sim 5 \%)$ explained among groups.

\section{Phylogenetic and phylogeographic analysis}

To determine phylogenetic affinities and origins of new orphan haplotypes, the Bayesian reconstruction included the 17 haplotypes from Ecuador plus additional haplotypes from GenBank. Ecuadorian haplotypes from nesting individuals were nested within 2 previously recognized clades (Fig. 2): (1) CP-EP Clade (Dutton et al. 2014a) and (2) a WP clade (Dethmers et al. 2006, Naro-Maciel et al. 2014). The CP-EP clade includes 3 subclades with samples from Hawaii, Revillagigedo, Michoacán, Costa Rica, Galápagos (Dutton et al. 2014a), and MNP in coastal Ecuador. The lack of support in several clusters within the CP-EP clades failed to recover the monophyletic clades as reported by Dutton et al. (2014a). Nevertheless, the Bayesian tree supports the genetic foraging aggregations (CmP97.1, CmP112.1, and CmP22.1) corresponded to haplotypes found in $\mathrm{CP}$ and WP. Haplotype CmP22.1 has been found in nesting rookeries from American Samoa, the Marshall Islands, and Ulithi Atoll (Dutton et al. 2014b), while the orphan haplotypes CmP97.1 and CmP112.1 are phylogenetically related to WP rookeries (Fig. 2) (Dutton et al. 2014a, Naro-Maciel et al. 2014, P. H. Dutton unpubl.). The last 3 haplotypes were found in $19.7 \%$ of GPS foraging grounds and in $4.6 \%$ of the MNP foraging aggregation.

The Bayesian calibrated tree supports the origin of green turtles in the Pliocene ca. 4.40 million yr (HPD $=2.70-6.37$; stem-based estimate) falling within the range proposed using whole mitogenone calibration (Duchene et al. 2012). Our tree also suggests a young origin $(<0.1$ million yr) for all haplotypes found in Ecuadorian rookeries.

The haplotype network of Ecuadorian rookeries (MNP and GPS; Fig. 3) showed most nesting females bearing the aforementioned common haplotypes (CmP4.6, CmP4.7, and CmP4.1; see also Table 1), and few individuals characterized by less common haplotypes that had connections of $1 \mathrm{bp}$ in a star-like fashion. The 3 common haplotypes were also commonly found in several individuals from Michoacán and Revillagigedo when pooled with data from GenBank (see Dutton et al. 2014a).

\section{MSA}

MSA was performed using only haplotypes with known origin. Because MNP and GPS nesting populations were not significantly different (population genetic results), these 2 stocks were pooled into a single GPS-MNP entity for subsequent analyses. The MSA was run using uniform and weighted priors (population size, distance from source rookery); however, weighted priors are only useful for estimating source contributions when the estimates using uni- 


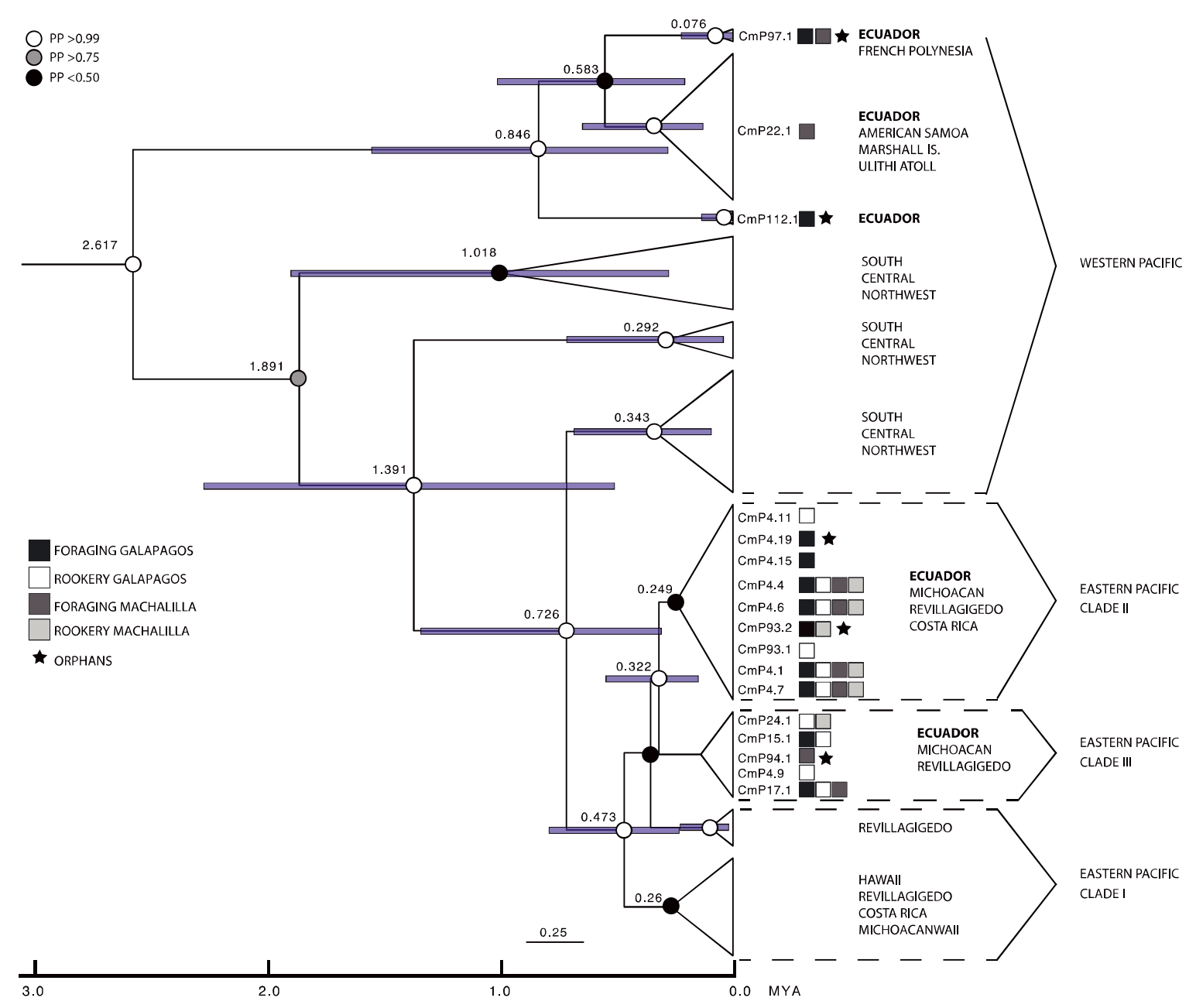

Fig. 2. Phylogenetic reconstruction of green turtle Chelonia mydas mitochondrial DNA control region haplotypes combining sequences from this study and those from Dutton et al. (2014a). Only haplotypes found in Ecuador are labeled with standard nomenclature. Boxes with different shading next to haplotypes indicate their presence in foraging aggregations in the GPS (black squares) or MNP (dark grey squares), or in rookeries in GPS (white squares) or MNP (light grey squares). Orphan haplotypes are marked with a star. Mean marginal means for age estimates are shown as blue bars on nodes. Scale at bottom is in millions of years. Haplotype names follow Table 1. Terminal branches were collapsed (triangles) and outgroups removed for better visualization. PP: posterior probability

form priors (based on stock haplotype frequencies only) fail to provide explanatory results. In our case, the uniform prior provided a reasonable estimate on the contributions by the major stocks to the analyzed foraging grounds, on which we focus hereafter. The estimated contributions indicate a predominance of the combined GPS-MNP stock to both foraging grounds with average contributions of around $96.5 \%$ (95\% to GPS and $98 \%$ to MNP; Table 4, Fig. S1 in the Supplement at www.int-res.com/ articles/suppl/n032p251_supp.pdf). The Michoacán source appeared to
Table 4. Mixed stock analysis estimated contributions of Pacific green turtle Chelonia mydas stocks to Machalilla National Park (MNP) and Galápagos (GPS) foraging aggregations. Results are shown for flat-prior analysis only (mean and $95 \%$ confidence intervals are indicated). Estimated contributions $>5 \%$ are shown in bold; blank cells indicate no data

\begin{tabular}{|lrrrrrr|}
\hline \multirow{2}{*}{ Stock } & \multicolumn{3}{c}{ MNP } & & \multicolumn{2}{c|}{ GPS } \\
\cline { 2 - 3 } & Mean & CI (95\%) & & Mean & CI (95\%) \\
\hline Revillagigedo (Mexico) & 0.41 & $0.00-3.71$ & & 0.56 & $0.00-4.14$ \\
Michoacán (Mexico) & 1.02 & $0.00-\mathbf{8 . 8 3}$ & & 1.26 & $0.00-\mathbf{9 . 2 9}$ \\
Nombre de Jesús (Costa Rica) & 0.77 & $0.00-\mathbf{6 . 7 2}$ & & 0.78 & $0.00-\mathbf{5 . 9 5}$ \\
GPS-MNP & $\mathbf{9 4 . 8 9}$ & $\mathbf{7 2 . 9 5 - 9 6 . 6 4}$ & & $\mathbf{9 6 . 9 8}$ & $\mathbf{8 7 . 3 3 - 9 9 . 9 7}$ \\
Hawaii & 0.69 & $0.00-2.84$ & & 0.42 & $0.00-3.15$ \\
American Samoa & 1.16 & $0.00-\mathbf{1 1 . 1 5}$ & & \\
Ulithi Atoll & 1.16 & $0.00-\mathbf{1 0 . 9 6}$ & & \\
Marshall Islands & 1.13 & $0.00-\mathbf{1 0 . 6 8}$ & & \\
\hline
\end{tabular}




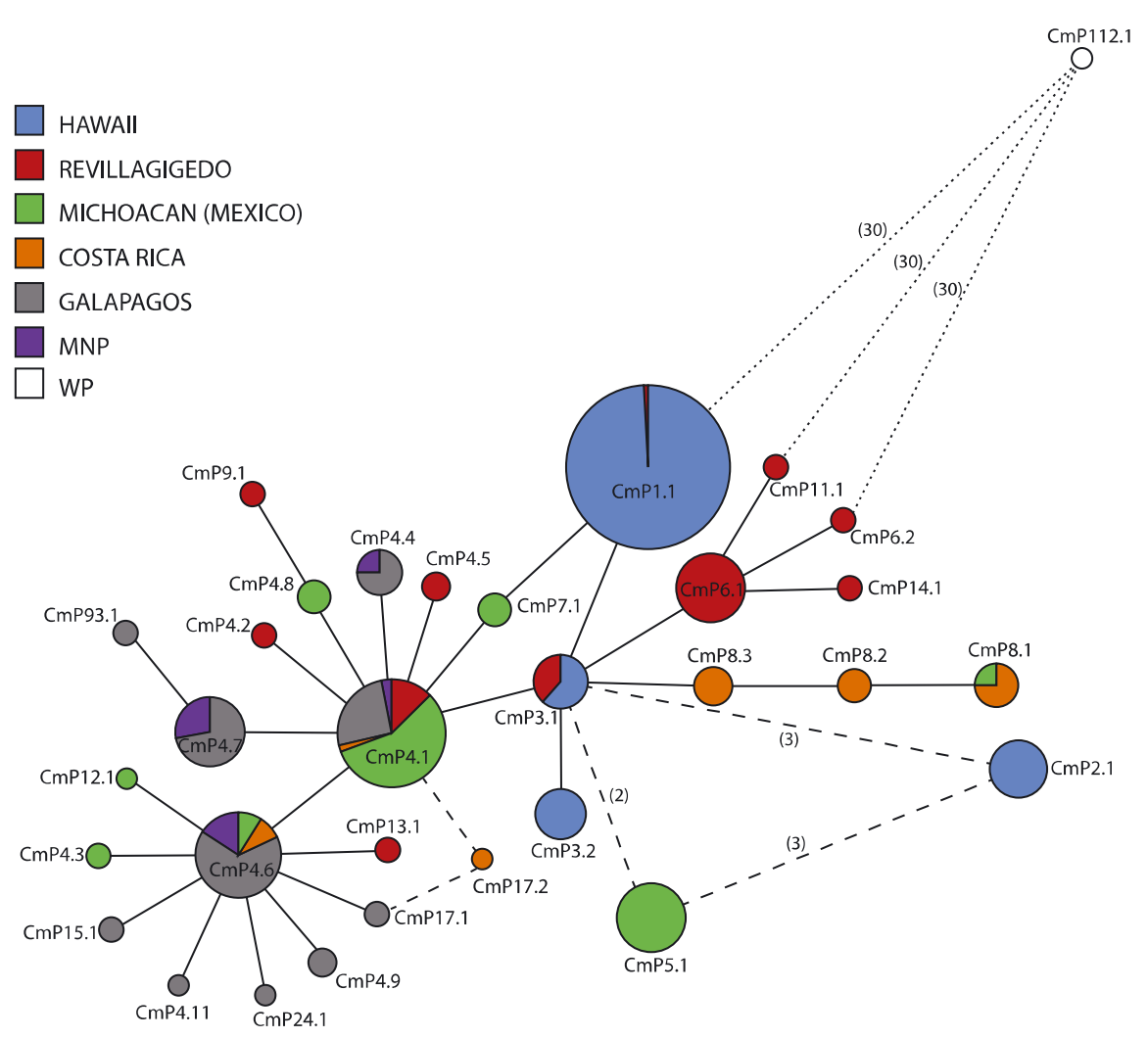

Fig. 3. Haplotype network of nesting green turtle Chelonia mydas mitochondrial control region haplotypes found in the Eastern Pacific. Each circle corresponds to a unique haplotype, the size is proportional to the number of sampled individuals carrying that haplotype over all data used (this study + Dutton et al. 2014a), and the connections represent 1 base pair (bp) difference unless specified otherwise (number in parentheses). Dashed lines correspond to alternative haplotype connections, and dotted lines depict connections of $30 \mathrm{bp}$. Haplotype names reported in Ecuador follow Table 1. MNP: Machalilla National Park, WP: Western Pacific

provide a small contribution of 1.3 and $1.0 \%$ to GPS and MNP, respectively. For MNP, a minimal contribution of 1.2 and $1.1 \%$ was estimated to come from American Samoa and Micronesia (Ulithi Atoll and Marshall Islands), respectively. The estimated contributions to both Ecuadorian foraging grounds from Revillagigedo Archipelago, Nombre de Jesús (Costa Rica), and Hawaiian rookeries were negligible (mean of $\leq 1.0 \%$ ). Given that, with the exception of the Ecuadorian sources, all estimates include 0 within their confidence limits, it is likely that only the Ecuadorian rookeries contribute to the foraging sites under study (Table 4).

\section{Morphological diversity of foraging individuals}

Size class histograms show a substantial number of immature individuals in both foraging grounds. Based on the cut-off size of $70 \mathrm{~cm}$ to distinguish immature from mature individuals (see 'Materials and methods'), we recorded a total of 18 immature/juveniles $(<70 \mathrm{~cm}$ CCL) and 43 adults ( $>70 \mathrm{~cm} \mathrm{CCL),} \mathrm{of} \mathrm{which} 20$ were females and 23 males (Fig. S2 in the Supplement). On the other hand, MNP foraging individuals were dominated by immature/juvenile turtles $(\mathrm{n}=26)$. Remaining adult individuals sampled were 11 females and 6 males (Fig. S2). In both foraging aggregations, all WP haplotype-bearing individuals $(\mathrm{CmP}$ 97.1, CmP 112.1, and $\mathrm{CmP} 22.1$ ) (Fig. S2) corresponded to turtles with yellow morphotypes; all 4 immature/juvenile individuals for GPS (mean CCL $=53.75 \mathrm{~cm}$, range $=44-76$ ) and 1 female in MNP $(\mathrm{CCL}=73 \mathrm{~cm})$. Nesting females in MNP presented a mean CCL of $86.52 \mathrm{~cm}(\mathrm{n}=27$; $\mathrm{SD}=5.25 \mathrm{~cm}$, range $=77.3-98.0 \mathrm{~cm}$ ).

\section{DISCUSSION}

\section{Rookeries}

The genetic similarity found between coastal Ecuador (MNP) and Galapagos rookeries (GPS) suggests that these 2 nesting assemblages are behaving as a single panmictic stock. Both nesting sites share unique haplotypes (CmP4.4 and $\mathrm{CmP4.7})$, and shared haplotypes ( $\mathrm{CmP4.1}$ and $\mathrm{CmP4}$.6) found in green turtle nesting beaches across the EP (Table S1: Hawaii, Michoacán, and Costa Rica). Although green turtle rookeries that are more than $500 \mathrm{~km}$ apart may behave as independent stocks (Dethmers et al. 2006, Bowen \& Karl 2007, Dutton et al. 2014b, Shamblin et al. 2015), the GPS and MNP rookeries are genetically similar despite the fact that they are about $1000 \mathrm{~km}$ apart. However, our results were not unexpected given that a similar pattern was found between GPS and Mexican rookeries using nuclear microsatellites and mtDNA data over larger distances than those pre- 
sented here (Dethmers et al. 2006, Dutton et al. 2008). We hypothesize that this finding might be explained by at least 3 scenarios: (1) high levels of ongoing gene flow between GPS and MNP females, (2) recent colonization of nesting females to either of these beaches with little time for genetic differentiation (i.e. evolutionary connectivity), or (3) insufficient resolution using currently available genetic markers. Although none of these were explicitly tested here, our timecalibrated tree coincides with a very recent origin for the region's haplotypes ( $<0.1$ million yr). Furthermore, the star-like haplotype network for MNP and GPS rookeries (Fig. 3) revealed little genetic structure. This result is indicative of recent shared ancestry or recent divergence of several endemic haplotypes separated by $1 \mathrm{bp}$ from more common and widely distributed haplotypes, ultimately suggesting recent colonization (see Avise 2000). A common limitation of the use of mtDNA in marine turtle studies in general is the difficulty to detect population structure at fine scales (reviewed by Bowen \& Karl 2007).

We recognize that a more accurate estimate of gene flow between highly similar rookeries from MNP and GPS could require a combination of both nuclear and mitochondrial DNA (bi-parental and female-mediated gene flow) markers. Alternatively, the use of mitochondrial short tandem repeats (Tikochinski et al. 2012) or mitogenomic sequencing could help reveal cryptic differentiation among Ecuadorian populations, as found in Caribbean rookeries (Shamblin et al. 2012). Despite the limitations, these are robust results which suggest close genetic links between the Ecuadorian stocks in spite of their geographic separation that could be used as the first step in redefining MUs for these populations. At a regional scale, and besides the sharing of common haplotypes between MNP and GPS, the haplotype network showed that MNP nesting females shared haplotypes with individuals breeding in Mexico and Costa Rica ( $\mathrm{CmP4}$.6 and CmP4.7; Fig. 3). The MNP is apparently an important nesting area for green turtles that share genetic ties with other rookeries along the EP. Thus, our study expands the geographic distribution of these haplotypes in the EP to the newly sampled MNP beaches.

\section{Foraging grounds}

Foraging grounds at MNP and GPS exhibited relatively high $\pi$ and $h$ diversity, characteristic of habitats with a mixture of diverse local haplotypes (high $h$ ) with highly divergent haplotypes (high $\pi$ ). The largest difference in nucleotide diversity between GPS and MNP foraging grounds (GPS $\pi=0.014$ vs. MNP $\pi$ $=0.005$ ) clearly reflects this pattern where apparent WP haplotypes were more abundant in GPS waters $(18 \%)$ than in MNP (<5\%) (Table S2). Furthermore, only the nucleotide-based measure of genetic distance (and not haplotype frequency measures) was significant between these regions, consistent with the presence of highly divergent haplotypes found in GPS foraging individuals. The observed differences were non-significant when removing these WP haplotypes from the analysis, which is clear evidence of their influence inflating values of $\pi$, thus increasing the genetic composition of the foraging population in GPS. The orphan haplotype CmP97.1, closely related to foraging haplotypes from Palmyra Atoll (NaroMaciel et al. 2014), was found in 12 of 61 (19.67\%) turtles from GPS foraging grounds, and was previously also reported from foraging grounds off Gorgona Island in Colombia (Amorocho et al. 2012). The orphan and new haplotype CmP112.1, which is phylogenetically related to WP rookeries, was found at much lower frequency $(4.91 \%, 3$ out of 61$)$ in the GPS foraging grounds (2 immature and 1 mature female; Fig. S2). While their exact origins remain unknown, Ecuadorian individuals carrying these 2 orphan haplotypes exhibit the 'yellow morphotype' characteristic of WP green turtles (see Zárate 2012), which offers a possible clue to their origins. The apparent orphan haplotypes, along with the previously reported CmP22.1 from American Samoa, Marshall Islands, and Ulithi Atoll (Dutton et al. 2014b), represent evidence for trans-Pacific associations, suggesting that trans-oceanic links among Pacific green turtles are more widespread than previously thought for the species but not unique among sea turtles (Caretta caretta: Bowen et al. 1995, Dermochelys coriacea: Dutton et al. 2000). A simple visualization of passive drift movements by oceanic currents (adrift.org.au) from putative $\mathrm{CP}$ and WP sites provide possible routes to EP regions (e.g. GPS, MNP, and Gorgona; Amorocho et al. 2012). Thus, dispersal of individuals carrying WP haplotypes could be facilitated towards eastern regions either via the South Equatorial current in combination with the Humboldt Current from the south, or the North Equatorial current in combination with El Niño from the north. Previous satellite telemetry studies (C. caretta, D. coriacea, Eretmochelys imbricata: Mast et al. 2016) and tag recovery from hatchlings captured in longline fisheries $(C$. caretta; Boyle et al. 2009) have identified the importance of these dynamic oceanic currents in sea turtle movements. Thus, these currents could not only explain the presence of trans-Pacific haplotypes in 
the EP, but could also be responsible for the genetic patterns of connectivity reported here between GPS and MNP at a much smaller geographic scale.

In a regional comparison, and excluding divergent WP haplotypes from our analyses, the nucleotide diversity in GPS foraging grounds $(\pi=0.002)$ is within the ranges found at other previously studied foraging aggregations, such as the ones in CP $(0.002-$ 0.003, Hawaii; Dutton et al. 2008), Caribbean (0.003, Costa Rica; Bjorndal et al. 2005), and Atlantic (0.002-0.006, Brazili Naro-Maciel et al. 2006). However, when incorporated, the WP haplotypes inflate this population genetic metric $(\pi=0.013)$, placing the GPS aggregation within much higher ranges like those found at EP foraging aggregations (0.011, Colombia; Amorocho et al. 2012). This result highlights the importance of GPS foraging grounds contributing to the genetic diversity of green turtles in the EP. One such case is the orphan $C m P 4.15$, a rare haplotype found in 1 individual in GPS foraging grounds and phylogenetically linked to haplotypes found in rookeries from Ecuador and Mexico. Recent reports from Gorgona Island in Colombia have found this same haplotype in other foraging individuals (M. Sanchez pers. comm.), thus indicating a broad distribution regardless of its source. Further sampling on rookeries along the EP coast of South, Central, and North America will be important to identify its origin. Furthermore, the number of orphan haplotypes clustering within EP clades reported here (CmP4.19, CmP93.2 about $3 \%$ of all foraging turtles) and elsewhere (CmP94.1; Dutton et al. 2014a) could suggest either the presence of many genetically uncharacterized nesting stocks in the EP region, or the presence of rare local haplotypes that have not been detected due to small sample sizes studied at rookeries.

\section{MSA}

Our MSA results showed a predominance of a GPS-MNP contribution to both foraging grounds (93.8\% to GPS and $94.1 \%$ to MNP), revealing a very high degree of connectivity between rookery and foraging grounds in Ecuador. High connectivity among regional green turtles has also been documented within the Hawaiian MU, where most of the haplotypes found in foraging aggregations have their origins at proximate Hawaiian rookeries (Dutton et al. 2008). Extremely low contributions to Ecuadorian foraging grounds from regional stocks (e.g. Costa Rica and Mexico), could suggest a pattern for many foraging grounds along the EP composed mostly of local
MUs. On the other hand, foraging grounds in this study are found at the easternmost edge of the geographic range for green turtles in the EP, which may explain the limited exchange with other rookeries. Nevertheless, this pattern does not exclude the possibility that individuals from local rookeries may feed at multiple, common foraging grounds. For example, foraging turtles from GPS are mostly from rookeries in GPS, but turtles from GPS rookeries could also use foraging grounds in GPS, MNP, and Gorgona Island and coastal areas in Central America, as supported by post-nesting satellite-tacked individuals from GPS (Seminoff et al. 2008). This is consistent with their life histories, since no breeding takes place at foraging habitats. The lack of genetic differentiation combined with the MSA results supports a high connectivity between MNP and GPS, and suggests the existence of an important marine corridor connecting these 2 regions in Ecuador. Amorocho et al. (2012) found that a high percentage of Gorgona green turtles in Colombia have their origins in GPS nesting beaches. These findings together provide evidence for yet another axis of marine gateways in this region with important conservation implications.

\section{Implications for management and conservation}

Our study contributes information on the genetic diversity and connectivity of green turtles found in an important region of Ecuador (MNP) that had been unstudied. The existing data from GPS rookeries and newly published breeding haplotypes from MNP could be used to reassess the composition of green turtles in the southern range of the EP. The evidence implies that green turtles born in GPS utilize MNP as foraging grounds and vice versa, and hence conservation efforts in both areas are required to protect these 2 genetic stocks. On the basis of the present results, it would be justifiable to extend the previously defined Galápagos MU (Dutton et al. 2014a) to include the continental Ecuador rookeries (MNP). A series of pervasive anthropogenic threats including loss of habitat, coastal development, effect of fishery by-catch, poaching, boat strikes, and climate change are thought to determine marine turtle survival in the region. Although both nesting sites and waters are currently protected under Ecuadorian National Park regulations, the potential impacts from these activities are more evident in MNP (Peña-Mosquera 2010). Including MNP populations in the Galápagos MU would allow for rapid implementation of conservation strategies for coastal populations of green turtles 
using the better consolidated conservation scope applied to green turtles in the iconic Galápagos Islands. Another possibility is to extend the current protection of the EP Tropical Marine Corridor to incorporate MNP within this axis of international conservation efforts, a suggestion that stems from the important connectivity shown between MNP, GPS, and Gorgona in Colombia (Amorocho et al. 2012), which should encourage cooperative national and international efforts to reduce anthropogenic effects primarily in MNP. This habitat is valuable regionally not only for green turtles but for multiple marine turtle species, including the Critically Endangered hawksbill. More broadly, and since a significant portion of the turtles at foraging sites in Ecuadorian waters appear to be of WP origin, our study stresses the importance of the conservation value for this region by extending conservation attention across the Pacific, reaching the opposite side of the ocean basin. Finally, and given that the origin of many orphan foraging individuals in the region remains unresolved, we recommend exploration of potential rookery sites north and south of MNP to improve conservation efforts for green turtles along the EP.

Acknowledgements. We thank the Tortuga Negra-Galápagos project and all the people involved, and the following institutions for their support: Galápagos Science Center, Universidad San Francisco de Quito, GAIAS, Parque Nacional Galápagos, Parque Nacional Machalilla, University of North Carolina at Chapel Hill, Equilibrio Azul, Pontificia Universidad Católica del Ecuador, SharkSky-Galápagos, and James Cook University. This work was possible under permits authorized by the Ministerio del Ambiente (005-DRM-MA, 011-DRM-MA) and the Parque Nacional Galápagos (PC-20-14). We thank the following people for their valuable support: Daniela Alarcón-Ruales, Jason G. Castaneda, Carlos F. Mena, Stephen Walsh, Andrés Baquero, Maximilian Hirschfeld, Judith Denkinger, Leandro Vaca-Pita, Daniela Matheus-Holland, Andrés Leon, Cori Lopazanski, Cristian Quintero, Federico Idrovo-Bermeo, Juan García, Jorge Torres, Maryuri Yépez, Galo Quezada, Silvya Sotamba, Sofia Tacle, Danilo Silva, and Ernesto Briones. Antonio León, Maria de Lourdes Torres, and Gabriela Castillo provided laboratory support. We are grateful to Alexander Gaos, Michael Jensen, Ryan Harrigan, and John Rowe for comments that greatly improved the manuscript. Funds were provided by Ecofondo, Pontificia Universidad Católica del Ecuador, SENESCYT, the USFQ Chancellor Grant, and the Galápagos Science Center Research Grant.

\section{LITERATURE CITED}

Abreu-Grobois A, Horrocks J, Formia A, Dutton P and others (2006) New mtDNA Dloop primers which work for a variety of marine turtle species may increase the resolution of mixed stock analyses. In: Frick M, Panagopoulou
A, Rees AF, Williams K (comps) Book of abstracts. 26th Annu Symp Sea Turtle Biology. Island of Crete, Greece, 3-8 April 2006. International Sea Turtle Society, Athens, p 179 (Abstract only)

Amorocho DF, Abreu-Grobois FA, Dutton PH, Reina RD (2012) Multiple distant origins for green sea turtles aggregating off Gorgona Island in the Colombian Eastern Pacific. PLOS ONE 7:e31486

Anhalzer G, Ferrin JL, Baquero A, Vallejo F, Muñoz JP, Vera F Chalen X (2012) Machalilla National Park, a critical nesting site for hawksbill (Eretmochelys imbricata) and green (Chelonia mydas) sea turtles in the eastern Pacific. In: Jones TT, Wallace BP (comps) Proc 31st Annu Symp Sea Turtle Biology and Conservation, 10-16 April 2011, San Diego, CA. NOAA Tech Memo NMFS-SEFSC-631. NOAA Southeast Fisheries Science Center, Miami, FL, p 208-209 (Abstract only)

Avise JC (2000) Phylogeography: the history and formation of species. Harvard University Press, Cambridge, MA

Bass AL, Witzell WN (2000) Demographic composition of immature green turtles (Chelonia mydas) from the east central Florida coast: evidence from mtDNA markers. Herpetologica 56:357-367

Bjorndal KA, Bolten AB, Troëng S (2005) Population structure and genetic diversity in green turtles nesting at Tortuguero, Costa Rica, based on mitochondrial DNA control region sequences. Mar Biol 147:1449-1457

* Bolker B, Okuyama T, Bjorndal K, Bolten A (2003) Sea turtle stock estimation using genetic markers: accounting for sampling error of rare genotypes. Ecol Appl 13:763-775

Bolten AB (2003) Variation in sea turtle life history patterns: neritic vs. oceanic developmental stages. In: Lutz PL, Musick J, Wyneken J (eds) The biology of sea turtles, Vol 2. CRC Press, Boca Raton, FL, p 243-257

* Bolten AB, Bjorndal KA (1992) Blood profiles for a wild population of green turtles (Chelonia mydas) in the southern Bahamas: size-specific and sex-specific relationships. J Wildl Dis 28:407-413

*Bowen B, Karl S (2007) Population genetics and phylogeography of sea turtles. Mol Ecol 16:4886-4907

* Bowen BW, Meylan AB, Ross JP, Limpus CJ, Balazs GH, Avise JC (1992) Global population structure and natural history of the green turtle (Chelonia mydas) in terms of matriarchal phylogeny. Evolution 46:865-881

*Bowen BW, Abreu-Grobois FA, Balazs GH, Kamezaki N, Limpus CJ, Ferl RJ (1995) Trans-Pacific migrations of the loggerhead turtle (Caretta caretta) demonstrated with mitochondrial DNA markers. Proc Natl Acad Sci USA 92: 3731-3734

*Boyle MC, FitzSimmons NN, Limpus CJ, Kelez S, VelezZuazo X, Waycott M (2009) Evidence for transoceanic migrations by loggerhead sea turtles in the southern Pacific Ocean. Proc R Soc Lond B Biol Sci 276:1993-1999

Browne DC, Horrocks JA, Abreu-Grobois FA (2010) Population subdivision in hawksbill turtles nesting on Barbados, West Indies, determined from mitochondrial DNA control region sequences. Conserv Genet 11:1541-1546

Burnham KP, Anderson DR (2002) Model selection and multimodel inference: a practical information-theoretic Approach. Springer-Verlag, New York, NY

Carr A (1987) New perspectives on the pelagic stage of sea turtle development. Conserv Biol 1:103-121

Clement M, Posada D, Crandall KA (2000) TCS: a computer program to estimate gene geneologies. Mol Ecol 9: 1657-1659 
Dethmers KE, Broderick D, Moritz C, Fitzsimmons NN and others (2006) The genetic structure of Australasian green turtles (Chelonia mydas): exploring the geographical scale of genetic exchange. Mol Ecol 15:3931-3946

Dorummond A, Rambaut A (2007) BEAST: Bayesian evolutionary analysis by sampling trees. BMC Evol Biol 7:214

Duchene S, Frey A, Alfaro-Núñez A, Dutton PH, Gilbert MTP, Morin PA (2012) Marine turtle mitogenome phylogenetics and evolution. Mol Phylogenet Evol 65:241-250

Dutton PH, Balazs G, Dizon A, Barragan A (2000) Genetic stock identification and distribution of leatherbacks in the Pacific: potential effects on declining populations. In: Abreu-Grobois FA, Briseno-Duenas R, Marquez-Millán R, Sarti-Martinez L (eds) Proc 18th International Sea Turtle Symp. Tech Memo NMFS-SEFSC 436, US Dept Commerce, NOAA, Miami, FL, p 38-39 (Abstract only)

* Dutton PH, Balazs GH, LeRoux RA, Murakawa SKK, Zarate P, Martínez LS (2008) Composition of Hawaiian green turtle foraging aggregations: mtDNA evidence for a distinct regional population. Endang Species Res 5:37-44

Dutton PH, Jensen MP, Frey A, LaCasella E and others (2014a) Population structure and phylogeography reveal pathways of colonization by a migratory marine reptile (Chelonia mydas) in the central and eastern Pacific. Ecol Evol 4:4317-4331

Dutton PH, Jensen MP, Frutchey K, Frey A and others (2014b) Genetic stock structure of green turtle (Chelonia mydas) nesting populations across the Pacific Islands. Pac Sci 68:451-464

Engstrom TN, Meylan PA, Meylan AB (2002) Origin of juvenile loggerhead turtles (Caretta caretta) in a tropical developmental habitat in Caribbean Panama. Anim Conserv 5:125-133

Felsenstein J (1981) Evolutionary trees from DNA sequences: a maximum likelihood approach. J Mol Evol 17:368-376

Formia A, Godley B, Dontaine JF, Bruford M (2006) Mitochondrial DNA diversity and phylogeography of endangered green turtle (Chelonia mydas) populations in Africa. Conserv Genet 7:353-369

Gelman A, Rubin DB (1992) Inference from iterative simulation using multiple sequences. Stat Sci 7:457-472

Hamabata T, Kamezaki N, Hikida T (2014) Genetic structure of green turtle (Chelonia mydas) peripheral populations nesting in the northwestern Pacific rookeries: evidence for northern refugia and postglacial colonization. Mar Biol 161:495-507

Hamann M, Schäuble CS, Simon T, Evans S (2006) Demographic and health parameters of green sea turtles Chelonia mydas foraging in the Gulf of Carpentaria, Australia. Endang Species Res 2:81-88

Heidemeyer M (2015) Orígenes natales y migratorios de la agregación de tortuga negra (Chelonia mydas agassizii) en el hábitat de alimentación de la Isla del Coco basado en análisis de $\mathrm{ADN}$, bioquímicos y tecnología satelital. MSc thesis, Universidad de Costa Rica, San José

Jensen M (2010) Assessing the composition of green turtle (Chelonia mydas) foraging grounds in Australasia using mixed stock analyses. PhD dissertation, University of Canberra

Jensen M, FitzSimmons N, Dutton P (2013) Molecular genetics of sea turtles. In: Wyneken J, Lohmann K, Musick J (eds) Biology of sea turtles, Book III. CRC Press, Boca Raton, FL, p 134-154

Jensen MP, Bell I, Limpus CJ, Hamann M and others (2016)
Spatial and temporal genetic variation among size classes of green turtles (Chelonia mydas) provides information on oceanic dispersal and population dynamics. Mar Ecol Prog Ser 543:241-256

Joseph J, Nishizawa H, Arshaad WM, Kadir SAS and others (2016) Genetic stock compositions and natal origin of green turtle (Chelonia mydas) foraging at Brunei Bay. Glob Ecol Conserv 6:16-24

Kearse M, Moir R, Wilson A, Stones-Havas S and others (2012) Geneious Basic: an integrated and extendable desktop software platform for the organization and analysis of sequence data. Bioinformatics 28:1647-1649

Lohmann KJ, Witherington BE, Lohmann CMF, Salmon M (1997) Orientation, navigation, and natal beach homing in sea turtles. In: Lutz P, Musick J (eds) The biology of sea turtles. CRC Press, Boca Raton, FL, p 107-136

K Luschi P, Hays GC, Papi F (2003) A review of long distance movements by marine turtles, and the possible role of ocean currents. Oikos 103:293-302

Mast RB, Hutchinson BJ, Villegas PE (eds) (2016) State of the World's Sea Turtles (SWOT) Report, Book XI. Special Feature - South America. Oceanic Society, Ross, CA

Mayr E (1963) Animal species and evolution. Harvard University Press, Cambridge, MA

*Moncada F, Abreu-Grobois FA, Muhlia-Melo A, Bell C and others (2006) Movement patterns of green turtles (Chelonia mydas) in Cuba and adjacent Caribbean waters inferred from flipper tag recaptures. J Herpetol 40:22-34

Moritz C (1994) Applications of mitochondrial DNA analysis in conservation: a critical review. Mol Ecol 3:401-411

Musick JA, Limpus CJ, Lutz P, Musick J (1997) Habitat utilization and migration in juvenile sea turtles. In: Lutz $\mathrm{P}$, Musick J (eds) The biology of sea turtles. CRC Press, Boca Raton, FL, p 137-163

*Naro-Maciel E, Becker JH, Lima EHSM, Marcovaldi MÂ, DeSalle R (2006) Testing dispersal hypotheses in foraging green sea turtles (Chelonia mydas) of Brazil. J Hered 98:29-39

*Naro-Maciel E, Le M, FitzSimmons NN, Amato G (2008) Evolutionary relationships of marine turtles: a molecular phylogeny based on nuclear and mitochondrial genes. Mol Phylogenet Evol 49:659-662

*Naro-Maciel E, Gaughran SJ, Putman NF, Amato G and others (2014) Predicting connectivity of green turtles at Palmyra Atoll, central Pacific: a focus on mtDNA and dispersal modelling. J R Soc Interface 11:20130888

Nishizawa H, Naito Y, Suganuma H, Abe O and others (2013) Composition of green turtle feeding aggregations along the Japanese archipelago: implications for changes in composition with current flow. Mar Biol 160: 2671-2685

Nylander JAA, Wilgenbusch JC, Warren DL, Swofford DL (2008) AWTY (are we there yet?): a system for graphical exploration of MCMC convergence in Bayesian phylogenetics. Bioinformatics 24:581-583

Pella J, Masuda M (2001) Bayesian methods for analysis of stock mixtures from genetic characters. Fish Bull 99: $151-167$

Peña-Mosquera MP (2010) Diseño participativo de un plan de acción para la recuperación y conservación de las tortugas marinas en el Parque Nacional Machalilla, Manabí, Ecuador. MSc thesis, Universidad Internacional Menéndez Pelayo, Madrid

Peña-Mosquera MP, Baquero-Gallegos AB, Muñoz-Pérez JM, Puebla-Jiménez F, Alvarez V, Chalen-Noroña X 
(2009) El Parque Nacional Machalilla: zona crítica de anidación para la tortuga carey (Eretmochelys imbricata) y verde (Chelonia mydas) en el Ecuador y el Pacífico Oriental. Temporadas 2007-2009. www.equilibrioazul.org/ documentos/Publicaciones/Pe\%F1a\%20et\%20al_2009_ Anidacion_PNM_Equilibrioazul.pdf

Posada D (2008) jModelTest: phylogenetic model averaging. Mol Biol Evol 25:1253-1256

Proietti MC, Reisser JW, Kinas PG, Kerr R, Monteiro D, Marins LFF, Secchi ER (2012) Green turtle (Chelonia mydas) mixed stocks in the western South Atlantic, as revealed by mtDNA haplotypes and drifter trajectories. Mar Ecol 447:1-41

Rambaut A, Drummond AJ (2007) Tracer v1.4. http://beast. bio.ed.ac.uk/Tracer

Read TC, Wantiez L, Werry JM, Farman R, Petro G, Limpus CJ (2014) Migrations of green turtles (Chelonia mydas) between nesting and foraging grounds across the Coral Sea. PLOS ONE 9:e100083

Reynolds J, Weir BS, Cockerham CC (1983) Estimation of the coancestry coefficient: basis for a short-term genetic distance. Genetics 105:767-779

Roden SE, Morin PA, Frey A, Balazs GH, Zarate P, Cheng IJ, Dutton PH (2013) Green turtle population structure in the Pacific: new insights from single nucleotide polymorphisms and microsatellites. Endang Species Res 20: 227-234

Ronquist F, Huelsenbeck JP (2003) MRBAYES 3: Bayesian phylogenetic inference under mixed models. Bioinformatics 19:1572-1574

Schneider S, Roessli D, Excoffier L (2000) Arlequin v.2.0: a software for population genetics data analysis. Genetics and Biometry Laboratory, University of Geneva, Geneva

Seminoff JA, Zárate P, Coyne M, Foley DG, Parker D, Lyon BN, Dutton PH (2008) Post-nesting migrations of Galápagos green turtles Chelonia mydas in relation to oceanographic conditions: integrating satellite telemetry with remotely sensed ocean data. Endang Species Res 4:57-72

Shamblin BM, Bjorndal KA, Bolten AB, Hillis-Starr ZM, Lundgren IAN, Naro-Maciel E, Nairn CJ (2012) Mitogenomic sequences better resolve stock structure of

Editorial responsibility: Jeffrey Seminoff,

La Jolla, California, USA southern Greater Caribbean green turtle rookeries. Mol Ecol 21:2330-2340

Shamblin BM, Bagley DA, Ehrhart LM, Desjardin NA and others (2015) Genetic structure of Florida green turtle rookeries as indicated by mitochondrial DNA control region sequences. Conserv Genet 16:673-685

Tikochinski Y, Bendelac R, Barash A, Daya A, Levy Y, Friedmann A (2012) Mitochondrial DNA STR analysis as a tool for studying the green sea turtle (Chelonia mydas) populations: the Mediterranean Sea case study. Mar Genomics 6:17-24

Vieyra M (2006) A molecular approach to understanding the importance of olfaction in the life history of sea turtles: turtle olfactory receptor gene phylogeny, allelic diversity and evidence for selection. $\mathrm{PhD}$ dissertation, University of South Carolina, Columbia, SC

*Wallace BP, DiMatteo AD, Hurley BJ, Finkbeiner EM and others (2010) Regional management units for marine turtles: a novel framework for prioritizing conservation and research across multiple scales. PLOS ONE 5:e15465

WWard RD, Woodwark M, Skibinski DOF (1994) A comparison of genetic diversity levels in marine, freshwater, and anadromous fishes. J Fish Biol 44:213-232

Wibbels T (1999) Diagnosing the sex of sea turtles in foraging habitats. In: Eckert KL, Bjorndal KA, Abeu-Grobois FA, Donnelly M (eds) Research and management techniques for the conservation of sea turtles. Publication No. 4 1-5, Book 4. IUCN/SSC Marine Turtle Specialist Group, Washington, DC, p 139-144

Wyneken J, Lohmann KJ, Musick JA (eds) (2013) The biology of sea turtles, Vol III. CRC Press, Boca Raton, FL

Zárate P (2002) Evaluación de la actividad de anidación de la tortuga verde Chelonia mydas, en las islas Galápagos durante la temporada 2001. Fundación Charles Darwin, Puerto Ayora, Santa Cruz, Galápagos

Zárate P (2012) Offshore oasis: ecology of sea turtles at oceanic islands of the eastern Pacific. In: Seminoff JA, Wallace BP (eds) Sea turtles of the eastern Pacific: advances in research and conservation. Arizona-Sonora Desert Museum Studies in Natural History, p 63-87. The University of Arizona Press, Tucson, AZ

Submitted: May 13, 2016; Accepted: January 7, 2017 Proofs received from author(s): March 1, 2017 